\title{
Accuracy of periapical radiography, panoramic radiography and computed tomography for examining the mental foramen region
}

\author{
Acurácia de radiografia periapical, radiografia panorâmica e \\ tomografia computadorizada para exame da região do \\ forame mentual
}

\begin{abstract}
Purpose: To determine the accuracy of different radiographic methods for bone height estimation at the mental foramen area.

Methods: Twenty dry human hemimandibles were examed by using periapical and panoramic radiography, and computed tomography. An electronic digital caliper was used to measure the tracings obtained from the radiographies in three different times (groups A1, A2 and A3) and in the cross-sectioned hemimandibles (group B). Measurements consisted of: Measure 1 - from the upper limit of the alveolar ridge to the upper limit of the mental foramen; Measure 2 - from the upper limit of the mental foramen to the inferior limit of the cortical bone of the base of the jaw; Measure 3 - from the upper limit of the alveolar ridge to the inferior limit of the cortical bone of the base of the jaw. Data were analyzed with Student-t and Friedman tests.

Results: The average difference values in Measure 1 were $0.33 \mathrm{~mm}, 0.35 \mathrm{~mm}$ and $0.85 \mathrm{~mm}$ for the periapical radiography, computed tomography and panoramic radiography, respectively (confidence intervals of $0.17 \mathrm{~mm}$ to $0.49 \mathrm{~mm}, 0.18 \mathrm{~mm}$ to $0.53 \mathrm{~mm}$ and $0.38 \mathrm{~mm}$ to 1.32 $\mathrm{mm}$, respectively). Panoramic radiographies showed the greatest differences in Measures 2 and 3 , with average values of $1.05 \mathrm{~mm}$ and $1.93 \mathrm{~mm}$, respectively.

Conclusion: Periapical radiography and computed tomography showed the best accuracy. A safety margin for surgical purposes has been suggested.
\end{abstract}

Key words: Computed tomography; radiography; dental implants; diagnostic imaging; mental foramen

\section{Resumo}

Objetivo: Determinar a acurácia de diferentes métodos radiográficos para estimação de altura óssea na região do forame mentual.

Metodologia: Vinte hemi-mandíbulas humanas, secas, foram examinadas por radiografia periapical e panorâmica e tomografia computadorizada. Um paquímetro digital foi usado para medir os traçados obtidos das radiografias em três diferentes tempos (grupos A1, A2 e A3) e nas hemi-mandíbulas seccionadas transversalmente (grupo B). As medições foram: Medida 1 - do limite superior da crista óssea ao limite superior do forame mentual; Medida 2 - do limite superior do forame mentual ao limite inferior do osso cortical da base da mandíbula; Medida 3 - do limite superior da crista óssea ao limite inferior do osso cortical da base da mandíbula. Os dados foram analisados por teste $\dagger$ de Student e teste de Friedman.

Resultados: Os valores médios de diferença na Medida 1 foram 0,33 mm, 0,35 mm e 0,85 $\mathrm{mm}$ para a radiografia periapical, tomografia computadorizada e radiografia panorâmica, respectivamente (intervalos de confiança de 0,17 a 0,49 mm, 0,18 a 0,53 $\mathrm{mm}$ e 0,38 a $1,32 \mathrm{~mm}$, respectivamente). As radiografias panorâmicas mostraram as maiores diferenças nas Medidas 2 e 3, com valores médios de 1,05 mm e 1,93 mm, respectivamente.

Conclusão: A radiografia periapical e a tomografia computadorizada mostraram a melhor acurácia. Sugere-se uma margem de segurança em caso de cirurgias.

Palavras-chave: Tomografia computadorizada; radiografia; implantes dentários; diagnóstico por imagem; forame mentual

\author{
Alexandre Bahlis a \\ Luis André Mezzomo a \\ Daniel Boeckel a \\ Nilza Pereira da Costa a \\ Eduardo Rolim Teixeira ${ }^{a}$
}

a School of Dentistry, Pontifical Catholic University of Rio Grande do Sul, Porto Alegre, RS, Brazil

\author{
Correspondence: \\ Alexandre Bahlis \\ School of Dentistry \\ Pontifical Catholic University of \\ Rio Grande do Sul - PUCRS \\ Av. Ipiranga 6681 Prédio 6 sala 507 \\ Porto Alegre, RS - Brazil \\ 90619-900 \\ E-mail: alexandre.bahlis@pucrs.br
}

Received: February 2, 2010

Accepted: May 27, 2010

Conflict of Interest Statement: The authors state that there are no financial and personal conflicts of interest that could have inappropriately influenced their work.

Copyright: (C) 2010 Bahlis et al.; licensee EDIPUCRS This is an Open Access article distributed under the terms of the Creative Commons AttributionNoncommercial-No Derivative Works 3.0 Unported License. 


\section{Introduction}

The high success rates involved in the clinical application of dental implants depend on a thorough evaluation of the patient, being closely related to the correct prosthetic and surgical planning. Among other planning procedures, success becomes more predictable due to precise imaging evaluation of the implant surgical site. Consequently, radiographic exams are a valuable source for this purpose (1-3).

Placement of osseointegrated implants close to the mental foramen region requires a precise diagnosis and surgical planning, avoiding any possible damage to the mental nerve as well as to the inferior alveolar nerve. In a prospective follow-up of patients who underwent implant placement close to mental nerve in the mandible, $8(8.5 \%)$ out of 94 consecutive patients showed altered nerve sensation after their first post implant visit (4). Therefore, interest in the emergence and location of the mental nerve has been rekindled by the need for the accurate preoperative surgical planning for the placement of mandibular implants $(4,5)$. This area has been said to be very important in the planning of the number, distribution and placement of implants in the prosthetic rehabilitation of the mandible (6-8). Moreover, an anterior loop to the nerve before its emergence from the mental foramen has been described $(4,5)$. The extent of this loop is clinically significant, since the maximum separation of the implants between the mental foramina is a biomechanical necessity and the most distal implants are critical to the success of the prosthesis (5). In order to allow an appropriate implant treatment plan, a great development of several different image diagnostic tools such as periapical and panoramic radiographs as well as computed tomography has been observed, although the evidences on their actual accuracy and precision level is still contradictory (9-11).

Thus, the purpose of this study was to evaluate the accuracy of periapical and panoramic radiographies as well as computed tomography, through the comparison of vertical measurements obtained from radiographic images of dry jaws. Furthermore, an attempt has been done to determine the precision of the three methods when compared between themselves and to establish a safety margin for each radiographic exam.

\section{Materials and Methods}

Ten dry human mandibles have been used in this study. The mandibles have been evaluated at the mental foramen area bilaterally, ending up with twenty evaluated samples.

The panoramic radiographies were made with an Ortophos CD Plus device (Siemens Aktiengesellschaft ${ }^{\mathbb{Q}}$, Munich, Germany), under an electric regimen of $60 \mathrm{kVp}$ and $9 \mathrm{~mA}$, in the program P11 which has a $25 \%$ constant magnification. In order to mitigate the radiation levels, two lead sheets $0.1 \mathrm{~mm}$ wide, obtained from occlusal radiographic films $\mathrm{nr} .4$, were placed in front of the diaphragm. The radiographic film used was the TMat G/RA (Kodak ${ }^{\circledR}$, Rochester, New York, USA). Following the radiographic exams, the films were automatically processed in an AT 2000 machine (Air Techniques Co. ${ }^{\circledR}$, New York, USA) with a total development time of 4.5 minutes. The jaws were positioned according to the protocol established by the manufacturer, that is, with the base of the mandible positioned parallel to the ground. For this, mandibles were fixed to the panoramic device platform using a beading wax sheet (Clássico ${ }^{\circledR}$, Sao Paulo, Brazil), under orientation of its light guides on the midline of the mandible (Fig. 1).

The computed tomographies were made with a Philips CT Secura machine (Philips ${ }^{\circledR}$, Eindhoven, The Netherlands), under an electric regimen of $100 \mathrm{kVp}$ and $80 \mathrm{~mA}$ and with the gantry in an angulation of $0^{\circ}$. The base of the jaw was positioned perpendicular to the examining table (Fig. 2). The tomographies were reformatted in two dimensions (2D) in the software Philips Easy Vision 4.4 - Dental print (Philips ${ }^{\circledR}$, Eindhoven, The Netherlands), which follows the DentaScan protocol (GE Healthcare ${ }^{\circledR}$, United Kingdom), and printed in a 1:1 scale in an AGFA Scopix LT28 film (AGFA ${ }^{\circledR}$, Munich, Germany), using an AGFA Scopix LR 5200 printer (AGFA ${ }^{\circledR}$, Munich, Germany).

In order to do the periapical radiographies, two supports were fabricated - one with condensation silicone (Speedex Coltène Whaledent ${ }^{\mathbb{R}}$, Rio de Janeiro, Brazil), to position both the jaw and the film in such a way for obtaining the parallel technique; and the second one in acrylic resin $\left(\right.$ Clássico $^{\circledR}$, Sao Paulo, Brazil), which stabilized both the jaw, the silicone support and the soft tissue simulator.

Using the mental foramen as a reference, the jaws were cut with a fret saw (Polidental ${ }^{\circledR}$, Sao Paulo, Brazil), perpendicularly to their base and $15 \mathrm{~mm}$ distally to the anterior edge of the mental foramen to allow the right sample positioning during the examination. A Spectro $70 \mathrm{X}$ machine (Dabi Atlante ${ }^{\circledR}$, Ribeirao Preto, Sao Paulo, Brazil) under an electric regimen of $70 \mathrm{kVp}$ and $7 \mathrm{~mA}, 0.4 \mathrm{~s}$ of exposure time and $40 \mathrm{~cm}$ of focal distance has been used. Two beading wax sheets were used (Clássico ${ }^{\circledR}$, Sao Paulo, Brazil) as a soft tissue simulator (Fig. 3). The periapical film used was the Ultra-speed 2 (Kodak ${ }^{\circledR}$, Rochester, New York, USA). These exams were processed automatically in an AT 2000 machine (Air Techniques Co. ${ }^{\circledR}$, New York, USA) with the total time of 4.5 minutes (Fig. 3).

On a light box, in a dark room, a translucent paper was placed over the radiographic exams and a tracing line was drawn with a Pigma Mícron 01 pen (Sakura Color Products Corp. ${ }^{\circledR}$, Japan), which tip generated a $0.25 \mathrm{~mm}$ wide line for each individual area. The obtained drawings made up the A1 group, for the panoramic, tomography and periapical exams. This procedure has been repeated two more times, within a 1-week interval, making up A2 and A3 groups, for each exam, respectively.

The measurements were performed with an electronic digital caliper with a $0.01 \mathrm{~mm}$ resolution (The L.S. Starrett Company $^{\circledR}$, Jedburg, Scotland), both on the tracings and on the cross-sectioned jaws in the following order: Measure 1 - from the upper limit of the alveolar ridge to the upper limit of the mental foramen; Measure 2 - from the upper 


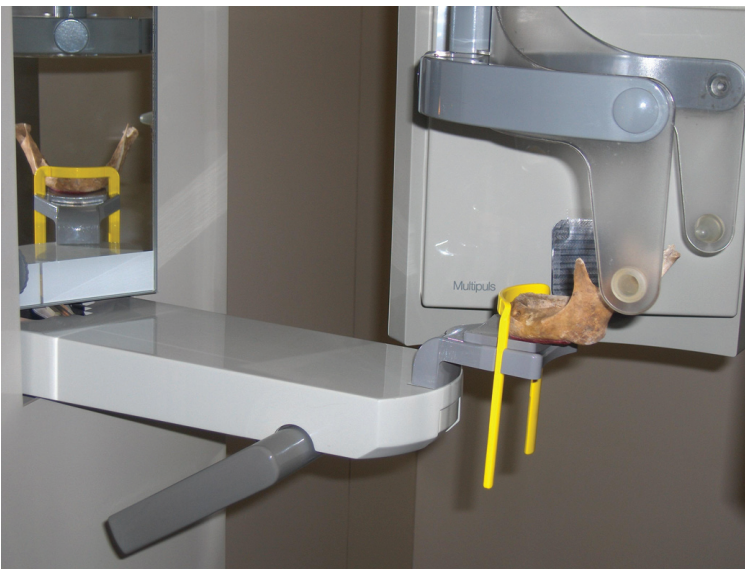

Fig. 1. Dry mandible positioned on the platform of the panoramic device.

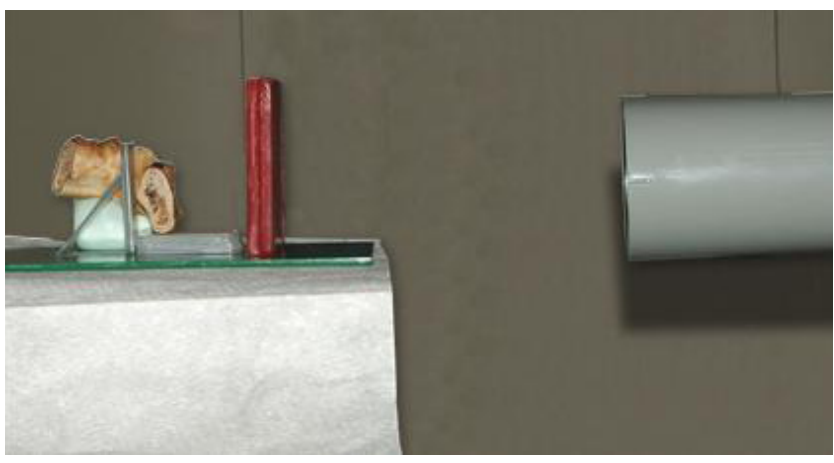

Fig. 3. Cross-sectioned jaw positioned for obtaining the periapical radiograph.

limit of the mental foramen to the inferior limit of the cortical bone of the base of the jaw; Measure 3 - from the upper limit of the alveolar ridge to the inferior limit of the cortical bone of the base of the jaw (Fig. 4). The measures in the jaws were considered the golden standard and made up group B.

\section{Statistical Analysis}

Ten tables were then made - three for the measures of the panoramic radiography, three for the computed tomography, three for the measures of the periapical radiography and one for the sectioned jaw measures. The measures of the panoramic radiography were written down on the tables with the corrected size (correcting the $25 \%$ magnification).

Having the three measurements for each exam, the Coefficient of Interclass Correlation statistical test was applied to evaluate the researcher's calibration and reproducibility. For the statistic test application, the mean results for the three measurements (A1, A2 and A3) on the panoramic, tomographic and periapical exams were calculated isolatedly, as well as the mean results for the measurements on the

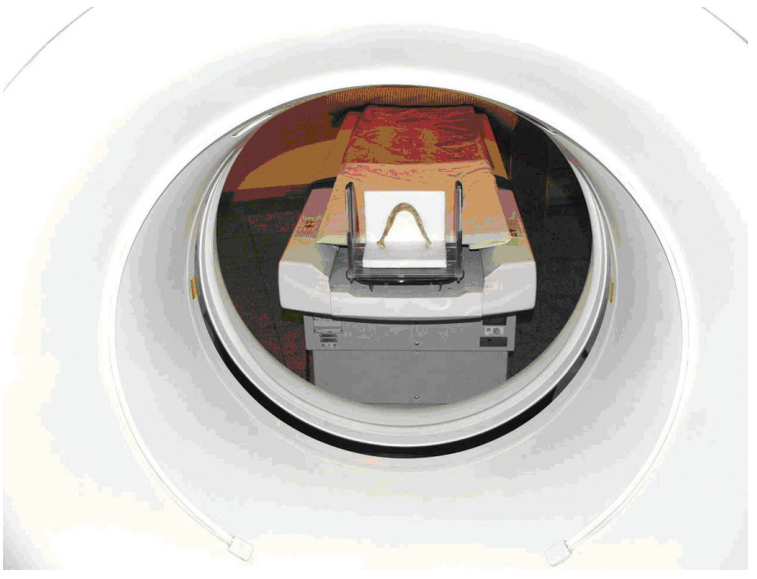

Fig. 2. Dry mandible positioned on the computed tomography machine.
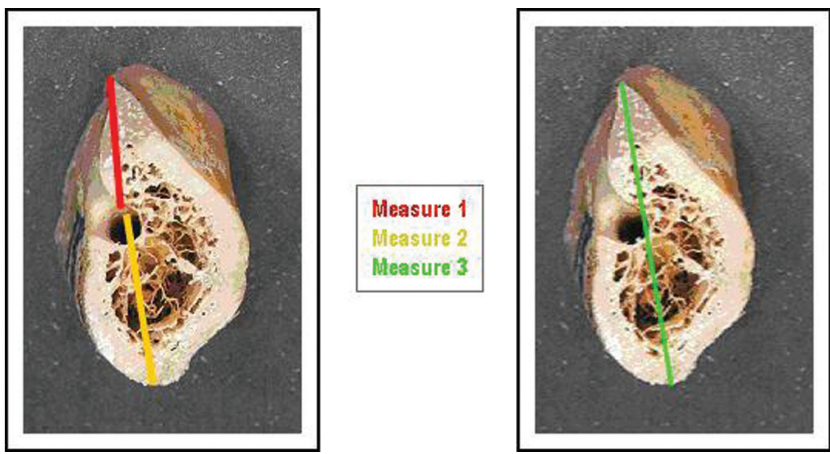

Fig. 4. Illustration of the measures made on the radiographic tracings and sectioned jaws.

specimen. The data were analyzed by using the $t$-Student test for paired data and the Friedman test.

\section{Results}

The Coefficient of Interclass Correlation statistical test showed a significant correlation in the measurements, on each radiographic model. Table 1 shows the results obtained from the t-Student test for the paired data.

For Measure 1 (Table 2), which was considered of greatest clinical relevance, periapical exam presented an average difference value of $0.33 \mathrm{~mm}$ when compared to the jaw, with a confidence interval of $0.17 \mathrm{~mm}$ to $0.49 \mathrm{~mm}$. For the computed tomography and panoramic radiography, the average difference values were $0.35 \mathrm{~mm}$ and $0.85 \mathrm{~mm}$, with confidence intervals of $0.18 \mathrm{~mm}$ to $0.53 \mathrm{~mm}$ and $0.38 \mathrm{~mm}$ to $1.32 \mathrm{~mm}$, respectively. In Measures 2 and 3, the greatest differences found were in the panoramic radiographies with average values of $1.05 \mathrm{~mm}$ and $1.93 \mathrm{~mm}$, respectively. Table 2 shows the results obtained from the Friedman nonparametric statistical test for paired data. 
Table 1. Radiography Exams comparison (isolated) with the jaws in $\mathrm{mm}$.

\begin{tabular}{|c|c|c|c|c|c|}
\hline Comparison & $\mathrm{n}$ & Mean & Standard deviation & Average difference & $P$ \\
\hline \multicolumn{6}{|l|}{ Periapical Radiography } \\
\hline Measure 1: Jaw & 20 & 11.21 & 2.66 & \multirow{2}{*}{0.33} & 0.01 \\
\hline Measure 1: Periapical & 20 & 10.88 & 2.60 & & \\
\hline Measure 2: Jaw & 20 & 15.14 & 1.80 & \multirow{2}{*}{-0.22} & 0.09 \\
\hline Measure 2: Periapical & 20 & 15.36 & 1.88 & & \\
\hline Measure 3: Jaw & 20 & 26.36 & 3.56 & \multirow{2}{*}{0.12} & 0.32 \\
\hline Measure 3: Periapical & 20 & 26.24 & 3.66 & & \\
\hline \multicolumn{6}{|l|}{ Panoramic Radiography } \\
\hline Measure 1: Jaw & 20 & 11.21 & 2.66 & \multirow{2}{*}{0.85} & 0.01 \\
\hline Measure 1: Panoramic & 20 & 10.36 & 3.09 & & \\
\hline Measure 2: Jaw & 20 & 15.14 & 1.80 & \multirow{2}{*}{1.05} & 0.01 \\
\hline Measure 2: Panoramic & 20 & 14.09 & 1.79 & & \\
\hline Measure 3: Jaw & 20 & 26.36 & 3.56 & \multirow{2}{*}{1.93} & 0.01 \\
\hline Measure 3: Panoramic & 20 & 24.43 & 3.71 & & \\
\hline \multicolumn{6}{|l|}{ Computed Tomography } \\
\hline Measure 1: Jaw & 20 & 11.21 & 2.66 & \multirow{2}{*}{0.35} & 0.01 \\
\hline Measure 1: Computed & 20 & 10.86 & 2.69 & & \\
\hline Measure 2: Jaw & 20 & 15.14 & 1.80 & \multirow{2}{*}{-0.26} & $0.05^{*}$ \\
\hline Measure 2: Computed & 20 & 15.41 & 1.71 & & \multirow{3}{*}{0.58} \\
\hline Measure 3: Jaw & 20 & 26.36 & 3.56 & \multirow{2}{*}{0.09} & \\
\hline Measure 3: Computed & 20 & 26.26 & 3.54 & & \\
\hline
\end{tabular}

Table 2. Radiography exam comparison with the differences for each method (jaws in mm)

\begin{tabular}{|c|c|c|c|c|c|c|}
\hline Comparison & $\mathrm{n}$ & Difference Mean & Standard Deviation & Average Ranking * & $\begin{array}{c}95 \% \text { Confidence } \\
\text { Interval }\end{array}$ & $P$ \\
\hline \multicolumn{7}{|l|}{ Measure 1} \\
\hline Periapical & 20 & 0.33 & 0.35 & $1.75^{\mathrm{A}}$ & {$[0.17-0.49]$} & \\
\hline Panoramic & 20 & 0.85 & 1.00 & $2.35^{A}$ & {$[0.38-1.32]$} & 0.14 \\
\hline Computed & 20 & 0.35 & 0.37 & $1.90^{A}$ & {$[0.18-0.53]$} & \\
\hline \multicolumn{7}{|l|}{ Measure 2} \\
\hline Periapical & 20 & -0.22 & 0.55 & $1.75^{\mathrm{A}}$ & {$[-0.47-0.04]$} & \\
\hline Panoramic & 20 & 1.05 & 1.14 & $2.75^{\mathrm{B}}$ & {$[0.52-1.59]$} & $0.01^{*}$ \\
\hline Computed & 20 & -0.26 & 0.57 & $1.50^{\mathrm{A}}$ & {$[-0.53-0.01]$} & \\
\hline \multicolumn{7}{|l|}{ Measure 3} \\
\hline Periapical & 20 & 0.12 & 0.51 & $1.50 \mathrm{~A}$ & {$[-0.12-0.35]$} & \\
\hline Panoramic & 20 & 1.93 & 1.42 & $2.90^{\mathrm{B}}$ & {$[1.26-2.59]$} & $0.01^{*}$ \\
\hline Computed & 20 & 0.09 & 0.74 & $1.60 \mathrm{~A}$ & {$[-0.25-0.44]$} & \\
\hline
\end{tabular}

* Values followed by the same letter are not statistically different.

\section{Discussion}

In this study, two statistic tests were used, aiming the proposed objectives. Firstly, the t-Student test for paired data compared each radiographic model isolatedly with the dry human mandible specimen. Periapical radiographies showed, when compared to the mandibles, a significant statistic difference in Measure 1 exclusively. These results present values lower than those related to the golden standard. When panoramic radiographies were compared with the jaws, a significant statistic difference was observed in the three measures, which underestimated the actual values. The computed tomography showed significant statistic differences in Measures 1 and 2, underestimating the golden standard values for the first measure and overestimating the values for the second measure. It was also observed the average values for the differences between the radiographic exams and the specimen.

Secondly, the Friedman non-parametric statistical test has been applied (Table 2). It compared all the radiographic models, aiming to identify the most accurate one, through the comparison of the average values from the differences between the specimen and the radiographies. A safety margin was established from the radiographic images evaluation and from the confidence interval calculation analysis.

The findings of the present experiment are in agreement with a previous paper (2). In that study, the authors made several measurements in both panoramic and computed tomographies obtained from a dry mandible. The panoramic radiography showed a magnification and a distortion which 
ranged from $4 \%$ to $16 \%$ and $-1 \%$ to $10 \%$, horizontally and vertically, respectively. The authors also claimed that dental implant treatment planning may be placing too much decision power on an imprecise diagnostic tool, and secondly, that the standard practice of assuming a $25 \%$ constant magnification for dental implant treatment planning may be unjustified. Finally, a panoramic, or any 2-D view, will give no information on the ridge width, undercuts or cross-sectional position of neurovascular bundles.

The distance between the upper limit of the alveolar ridge to the upper limit of the mental foramen image (measure 1), when overestimated, can result into a biological damage to the mental nerve as well as to the inferior alveolar nerve during implant procedures. On the other hand, when underestimated, it can lead to an implant length selection with a smaller size - therefore compromising the future of the osseointegration when a functional occlusion load over it is applied $(12,13)$. However, most recent studies showed that the length of the implant itself does not exert an important role on the rate of osseointegration $(14,15)$. In these studies, short implants $(8 \mathrm{~mm})$ with an enhanced surface showed similar survival rates than longer implants. This study is in accordance with previous researches $(2,9,16)$ which recognized being as a precise radiographic technique the one that shows differences inferior to $1.0 \mathrm{~mm}$ among the differences obtained from the radiography images and the real dimensions.

In this experiment, it was observed that the measures from the panoramic radiographies had the smallest precision and provided images with lower values to the real ones in the three measures. Similar results were found in previous studies $(2,12,17)$. However, when compared to the periapical exam and the computed tomography (Table 2), there was no statistically significant difference in Measure 1. The lack of sharpness and the distortions are inherent to the panoramic exam, once it is a radiographic technique sensitive to errors. It is useful in the preliminary phase of the diagnosis, providing the visual spatial relation of the anatomic structures, estimative of the vertical bone availability and showing the presence or absence of pathologies $(2,18,19)$.

In this study, the periapical exam has shown the best results. It was possible to position the radiographic film parallel to the alveolar process in all the samples and establish an adequate angle from the X-ray source, justifying the precision found in the results (20). However, in vivo, depending on the anatomic region, such positioning of the film might be difficult, generating imprecise results for vertical bone measures (21). Although the results were positive, we may take into account some limitations that this exam presents. In other words, this is a bidimensional representation of a tridimensional anatomic structure and covers a limited area due to the film size. Nevertheless, it is very helpful in the initial phases of the diagnosis and treatment planning, because it provides good quality images with details of the bones. Moreover, it offers a low dose of radiation and it is affordable to the patient (22).

The computed tomography has shown similar results to the periapical radiography (Table 2); that is, there was no statistically significant difference amongst them in the three measures. Although its radiation dose is considerably higher for all organs exposed than those reported for either panoramic or periapical radiographies (2), it has been suggested as the most appropriated exam in several clinical situations, due to its possibility of reformatting the images in three spatial plans. The successive and serial transversal slices (transversal plan) from the desired anatomic region are most used because they offer a clear and precise image of the vertical and horizontal dimensions, as well as the morphology. Therefore, in order to offer predictability to the implants and respective prosthesis, this exam provides the best selection of the implant dimensions and location, which are basic requisites to achieve biomechanical principals $(2,23)$. In the present study, no difficulty has been found to identify the mental foramen. However, with the computed tomography, it was possible to visualize more clearly this anatomic structure, as well as the inferior alveolar canal. The results of the panoramic radiography were not similar to the other radiographic exams due to the lack of clarity on the mental foramen edges.

According to the results from Table 2 and the analysis from the radiographic exams, a safety margin of $1.0 \mathrm{~mm}$ is suggested for the mental foramen region in the computed tomographies and the periapical exams. On the other hand, the safety margin hereby suggested for the panoramic radiographies is $2.0 \mathrm{~mm}$. These values corroborate the evidences claimed in previous studies $(4,24)$.

The prescription for radiographic exams should be based on clinical needs. The complexity degree of the surgical procedure is directly related to the anatomic region where the intervention will take place. The number of implants, the expected information from the image, the feasibility of the exam and the biological risks to the patients are relevant considerations in the selection and prescription of a radiographic technique.

\section{Conclusions}

In conclusion, the following statements can be done after the analysis and discussion of the results of this experimental study:

- For the vertical measurements, when each exam of the cut dry jaws was compared separatedly, the periapical radiography achieved the best results, followed by the computed tomography. On the other hand, panoramic radiography showed statistically significant differences in the three measures.

- When the exams were compared among themselves, the periapical radiography and the computed tomography presented similar results with the highest precision degree, followed by the panoramic radiography.

- It was possible to establish a safety margin for each radiographic exam. For both periapical radiography and computed tomography the safety margin suggested was $1.0 \mathrm{~mm}$ whereas for the panoramic radiography it was $2.0 \mathrm{~mm}$. 


\section{Acknowledgments}

This study was supported by a grant of the Coordination of Development of Senior Staff ("Coordenação de Aperfeiçoamento de Pessoal de Nivel Superior, CAPES”), Brazilian Ministry of Education.

\section{References}

1. Brånemark P-I, Zarb G, Albrektsson T. Introduction to osseointegration. In: Brånemark P-I, Zarb G, Albrektsson T. Tissue-integrated prosthesis - osseointegration in clinical dentistry. Chicago: Quintessence, 1985. p. $11-76$.

2. Reddy MS, Mayfield-Donahoo T, Vanderven FJJ, Jeffcoat MK. A comparison of diagnostic advantages of panoramic radiography and computed tomography scanning for placement of root form dental implants. Clin Oral Impl Res 1994;5:229-38.

3. Frederiksen NL. Diagnostic imaging in dental implantology. Oral Surg Oral Med Oral Pathol Oral Radiol Endod 1995;80:540-54.

4. Bartling R, Freeman K, Kraut RA. The incidence of altered sensation of the mental nerve after mandibular implant placement. J Oral Maxillofac Surg 1999;57:1408-12.

5. Kieser J, Kuzmanovic D, Payne A, Dennison J, Herbison P. Patterns of emergence of the human mental nerve. Arch Oral Biol 2002;47:743-7.

6. Lindh C, Petersson A. Radiologic examination for location of the mandibular canal: a comparison between panoramic radiography and conventional tomography. Int J Oral Maxillofac Impl $1989 ; 4: 249-53$

7. Stella JP, Tharanon WA. A precise radiographic method to determine the location of the inferior alveolar canal in the posterior edentulous mandible: implications for dental implants. Part 1: Technique. Int J Oral Maxillofac Impl 1990;5:15-22.

8. Cavalcanti MG, Yang J, Ruprecht A, Vannier MW. Validation of spiral computed tomography for dental implants. Dentomaxillofac Radiol 1998;27:329-33.

9. Klinge B, Petersson A, Maly P. Location of the mandibular canal: comparison of macroscopic findings, conventional radiography, and computed tomography. Int J Oral Maxillofac Impl 1989;4:327-32.

10. Thunthy KH, Yeadon WR, Nasr HF. An illustrative study of the role of tomograms for the placement of dental implants. J Oral Implantol 2003;29:91-5.

11. Guerrero ME, Jacobs R, Loubele M, Schutyser F, Suetens P, Van Steenberghe D. State-of-the-art on the cone beam CT imaging for preoperative planning of the implant placement. Clin Oral Investig 2006;10:1-7.

12. Lindh C, Petersson A, Klinge B. Measurements of distances related to the mandibular canal in radiographs. Clin Oral Impl Res 1995;6:96-103.
13. Ivanoff CJ, Sennerby L, Lekholm U. Influence of mono and bicortical anchorage on the integration of titanium implants. A study in the rabbit tibia. Int J Oral Maxillofac Surg 1996;25:229-35.

14. Grant BT, Pancko FX, Kraut RA. Outcomes of placing short dental implants in the posterior mandible: a retrospective study of 124 cases. J Oral Maxillofac Surg 2009;67:713-7.

15. Griffin TJ, Cheung WS. The use of short, wide implants in posterior areas with reduced bone height: a retrospective investigation. J Prosthet Dent 2004;92:139-44.

16. Bou Serhal C, Jacobs R, Quirynen M, Van Steenberghe D. Image technique selection for the preoperative planning of oral implants: a review of the literature. Clin Impl Dent Rel Res 2002;4: 156-72.

17. Batenburg RH, Stellingsma K, Raghoebar GM, Vissink A. Bone height measurements on panoramic radiographs: the effect of shape and position of edentulous mandibles. Oral Surg Oral Med Oral Pathol Oral Radiol Endod 1997;84:430-5.

18. Milles DA, Van Dis ML. Implant radiology. Dent Clin North Am 1993;37:645-68.

19. Stramotas S, Geenty JP, Petocz P, Darendeliler MA. Accuracy of linear and angular measurements on panoramic radiographs taken at various positions in vitro. Eur J Orthod 2002;24:43-52.

20. Gher ME, Richardson AC. The accuracy of dental radiographic techniques used for evaluation of implant fixture placement. Int J Perio Restor Dent 1995; 15:268-83.

21. Yang J, Cavalcanti MG, Ruprecht A, Vannier MW. 2-D and 3-D reconstructions of spiral computed tomography in localization of the inferior alveolar canal for dental implants. Oral Surg Oral Med Oral Pathol Oral Radiol Endod 1999;87:369-74.

22. Reiskin AB: Implant Imaging. Dent Clin North Am 1998;42: 47-56.

23. Silverstein LH, Melkonian RW, Kurtzman D, Garnick JJ, Lefkove MD. Linear tomography in conjuction with pantomography in the assessment of dental implant recipient sites. J Oral Implantol 1994;20:111-7.

24. Jacobs R, Adriansens A, Naert I, Quirynen M, Hermans R, Van Steenberghe D. Predictability of reformatted computed tomography for pre-operative planning of endosseus implants. Dentomaxillofac Radiol 1999;28:37-41. 